\title{
Protecting young people from sex without consent
}

Shireen J. Jejeebhoy

Population Council

Follow this and additional works at: https://knowledgecommons.popcouncil.org/departments_sbsr-pgy

Part of the Demography, Population, and Ecology Commons, Domestic and Intimate Partner Violence Commons, Family, Life Course, and Society Commons, Gender and Sexuality Commons, and the International Public Health Commons

How does access to this work benefit you? Let us know!

\section{Recommended Citation}

Jejeebhoy, Shireen J. 2011. "Protecting young people from sex without consent," Promoting Healthy, Safe, and Productive Transitions to Adulthood Brief no. 7. New York: Population Council. 


\section{Protecting young people from sex without consent}

\section{Prepared by Shireen J. Jejeebhoy}

O ver the last decade, a growing body of evidence - much of it the result of Population Council research-has laid to rest any illusion that the young are protected from unwanted sexual advances or forced sex both within and outside of marriage (Erulkar 2004; Bott, Guedes, and Guezmes 2005; Erulkar et al. 2005b; Hallman 2005; Jejeebhoy, Shah, and Thapa 2005; NRC and IM 2005). These studies have established the prevalence of unwanted sex within marriage among young women and its risk factors [Santhya and Jejeebhoy 2005 (India); Erulkar et al. 2005a (Ethiopia)]; the association between poverty and forced sex among adolescent girls in South Africa (Hallman 2005); and levels and correlates of forced sex reported by young people in Ethiopia and Kenya (Erulkar 2004; Erulkar et al. 2005b; Erulkar and Matheka 2007). A synthesis of evidence, moreover, has established that sex without consent among the young exists in every region of the world, and that girls, as well as, to a lesser extent, boys have experienced it (Jejeebhoy, Shah, and Thapa 2005).

Questions nevertheless remain. For example, to what extent have national policies responded to concerns about non-consensual sex among the young? Is it possible to track the prevalence of sex without consent in national and sub-national surveys? What are the health and social consequences of sex without consent? And most daunting, are there promising interventions that have succeeded in preventing sex without consent and/or in addressing its deleterious consequences? Highlights of research that has responded to these questions are summarized below.

Tracking the prevalence of sex without consent Increasingly, the Demographic and Health Surveys have fielded extensive modules to track the prevalence of physical and sexual violence experienced by women. Similarly, the World Health Organization's report on violence against women (WHO 2005) noted, for example, that between 6 percent (urban areas in Japan and Serbia) and 59 percent (Ethiopia) of women in the ten countries surveyed had ever

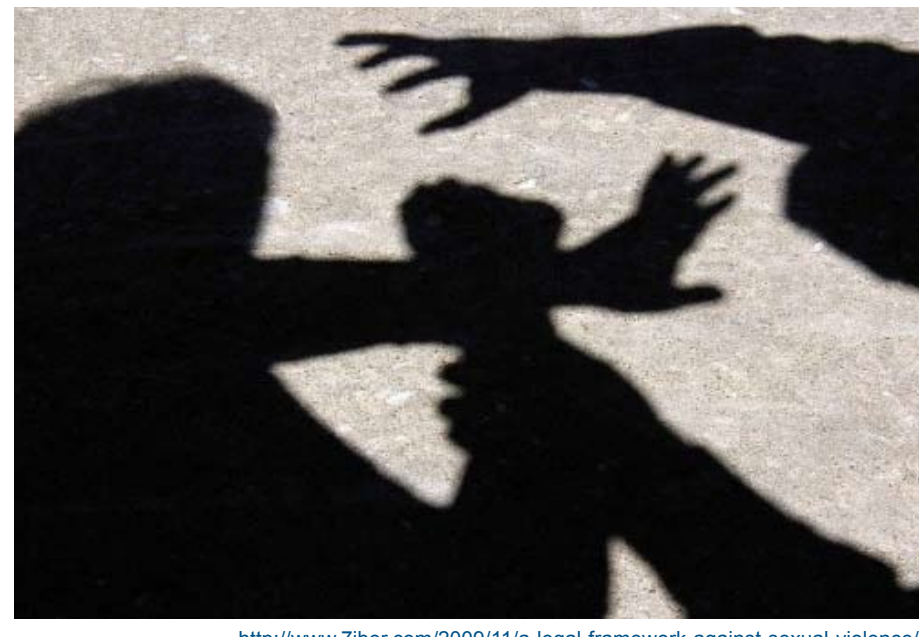

http://www.7iber.com/2009/11/a-legal-framework-against-sexual-violence/

experienced sexual violence, with most sites falling between 10 percent and 50 percent. In addition, studies focused exclusively on youth have made great strides in highlighting sex without consent among young men and women. Further analysis of DHS and other national data from 17 countries found that the proportion of young women (aged 15-24 years) whose first sexual experience was non-consensual ranged from 2 percent in Azerbaijan to 64 percent in the Democratic Republic of the Congo (Population Council 2010). Other national and sub-national studies have also documented sex without consent among youth. For example, evidence from the Philippines suggests that 27 percent of sexually experienced young women did not want to have sex the first time but went along, and 4 percent reported that sex was forced (Natividad and Marquez 2004). Moreover, the Youth in India: Situation and Needs study conducted by the International Institute for Population Sciences and the Population Council among youth in six states, representing two-fifths of India's population, noted that 15 percent of young women who reported pre-marital sex said that their first sexual encounter was forced, and another 14 percent said that it was per- 
suaded. Conversely, among unmarried young men, 21 percent reported that they had ever deliberately touched or brushed past a woman in a sexual way, and 4 percent reported that they had ever experienced such an unwanted touch. Forced sex was also evident within marriage. One-third of married young women reported forced sex within marriage, and 17 percent of young husbands admitted to forcing sex on their wife (IIPS and PC 2010).

These findings highlight the pervasiveness of sexual violence among the young, the need for periodic tracking of young people's experience of sex without consent in order to better gauge the extent to which programs have succeeded in reducing the practice, and the potential of routine surveys of youth and of health surveys more generally to incorporate such a regular tracking system.

\section{Non-consensual sex can be damaging on many levels}

The implications of non-consensual sex for young people's rights, their physical and mental health, and their social development are multifaceted. The consequences of non-consensual sex for the victim can be short- or long-term, leading to physical, psychological, or social harm (Koenig et al. 2005; Patel and Andrew 2005; Wu et al. 2006; Maharaj and Munthree 2007). Evidence shows that non-consensual sex among young people is associated with a range of risky subsequent behaviors in consensual relationships: early onset of consensual relations, unprotected sex, multiple partners, drug and alcohol abuse, and, in extreme cases, prostitution. Non-consensual sex has been associated with sexual and physical abuse in subsequent consensual relationships and, in the case of young men, its perpetration in subsequent sexual encounters. Social consequences of non-consensual sex are significant, ranging from poor educational achievement and withdrawal from school to an inability to build adult partnerships and a loss of marriage prospects. In many cases, victims are rejected by family or friends who react negatively to disclosure of the coercive incident. Health consequences are also observed-for example, unintended pregnancy and induced abortion among young women and sexually transmitted infections (STIs), including HIVIAIDS, among both females and males. Mental health consequences, moreover, range from feelings of worthlessness and depression to suicidal thoughts.

While many analysts have focused on adverse consequences among unmarried young people, recent evidence suggests that in settings where marriage occurs at young ages, married young women also suffer significant adverse sexual and reproductive health consequences. For example, a review of research in India, conducted by Council staff, suggests that young women who experienced sexual violence perpetrated by their husband were significantly more likely than other women to report an unmet need for contraception, the occurrence of induced abortion and fetal mortality, and symptoms of sexually transmitted infections. They were also significantly more likely to report symptoms of mental health problems (Jejeebhoy, Santhya, and Acharya 2010).

\section{Some interventions show promise}

While progress has been made over the last five years in understanding the extent and consequences of sex without consent among young people, few interventions explicitly address sexual coercion. Those that have done so in broader youth-focused programs have used a variety of strategies to address sexual and reproductive health needs of adolescents, including a focus on preventing sexual coercion. These programs have, for example, worked through sports associations (Brady and Khan 2002), life-skills and peer-support programs (Askew et al. 2004; Ajuwon and Brieger 2007; Jewkes et al. 2008), female mentorship/guardian programs (Mgalla et al. 1998), programs promoting HIV and reproductive health education, social networks and financial education (Hallman and Roca 2011), and workshops for men (Peacock and Levack 2004). Others have modified in-school sexuality education or life-skills curricula to include wider discussion of gender violence and sexual coercion (Ross et al. 2007). At the same time, school- and teacher-level interventions to change traditional misconceptions and build awareness of young people's rights have been pursued (Mirsky 2005). Still others have focused on improving the health service response by enhancing provider knowledge, attitudes, and practices, including the ability to detect and respond to cases of violence (Bott et al. 2005).

With the exception of the aforementioned studies, few interventions have been well documented and rigorously evaluated, and even fewer have assessed changes in sex without consent or related gender role attitudes. In short, there continues to be a gap in our awareness of what works; as a result, program planners and policymakers have little information about what strategies may be effective. The most we can say is that some approaches appear promising, a conclusion reached also in a recent UNIFEM report reviewing promising — but not scientifically evaluated-interventions to end violence against women and girls (UNIFEM 2010).

\section{Policy changes affecting sexual violence}

Over the last five years, policy attention to protecting women from domestic violence has increased in some settings. For example, in India, the Protection of Women from Domestic Violence Act 2005, passed in 2006, increased women's protection from violence and their options for redress. The Act's definition of domestic violence encompassed both actual abuse and the threat of abuse; moreover, it covered physical violence (beating, pushing), sexual violence (including being forced into sex or into watching pornography), and verbal, emotional, and economic violence (not providing for wife and children). The Act offers women considerable protection, including the right to reside in the matrimonial or shared household and the imposition of restraining orders on the perpetrator. In addition, under the Act, NGOs may register with the state as service providers, to support women through provision of legal aid, health care, economic support, and other social services.

Policy changes in South Africa went much further, taking steps to address the violation of children and adolescents. Its Sexual Offences 
Act (Sexual Offences and Related Matters Amendment Act of 2007) intensifies South Africa's efforts to fight sexual crimes and offenses against women, children, and adolescents, as well as the mentally disabled. It has expanded the definition of rape to include all forms of sexual penetration without consent, irrespective of gender, and the definition of sexual assault to all forms of sexual violence without consent, including displays of pornography, the creation of child pornography, and forced witnessing of sexual acts and certain parts of the human body. In addition, the Act criminalizes adult sexual penetration of adolescents between the ages of 12 and 16 years, even with their consent, and mandates imprisonment for not less than two years for sex offenders. It provides for health services, including post-exposure prophylaxis, as well as legal and other services intended to reduce secondary traumatization; and requires compulsory HIV testing of perpetrators. It also initiated the maintenance of a register of sex offenders and has established an interdisciplinary committee to advise the government on issues relating to non-consensual sex.

\section{Areas for future work and advocacy}

Health care providers and youth advocates-indeed society as a whole-must acknowledge the pervasiveness and context of sexual coercion. Sexual and reproductive health programs for young people as well as programs aimed at gender-based violence have not adequately addressed non-consensual sex. For instance, "ABC" messages, which advocate "Abstinence, the need to Be faithful, and Condom use," may not be pertinent either to the significant number of unmarried girls who confront non-consensual sex or to the significant number of married young women who face non-consensual sex perpetrated by their husband. Nor do they address the needs of young boys who experience non-consensual sex. Programs must recognize that young people face sexual coercion from a range of perpetrators-partners and husbands, peers, fathers and brothers, trusted authority figures, and so on -and that, therefore, the home, the school, and the health facility are not always safe places.

Programs and supportive messages should explicitly identify the behaviors that fall under the umbrella of non-consensual sex, acknowledge the context and pervasiveness of sexual coercion, and identify the scenarios in which it takes place. Traditional gender stereotypes must be countered, but such activities may need more thoughtful direction, since work on gender that addresses only masculinity issues among boys will ignore the adult men who force sex on adolescent girls. At the same time, the persistence of forced sex within marriage must be addressed; young men and women must be aware of women's rights in general and their right to refuse unwanted sex in particular, even if the perpetrator is the husband. Parents must be encouraged to discuss sensitive topics with their children, and they must learn to foster an environment that does not condone sexual coercion. Educational institutions and teachers need to prevent non-consensual sex, recognize and support young victims, and punish perpetrators (be they teachers or students). Likewise, health care providers need to recognize and inquire sensitively about non-consensual sex and counsel young people affected by coercive situations. The legal system must ensure that laws are protective, just, and implemented, including enforcement of legal age of marriage. Furthermore, young victims of coerced sex need some form of legal recourse.

Program implementation is thwarted by the paucity of evidencebased models highlighting successful prevention efforts. Few interventions have been rigorously evaluated, and few hold promise for replication and upscaling. Rigorous program evaluations are essential, and efforts need to be made to replicate and scale up successful models that protect young people from sex without consent.

Research is needed to better understand the context in which non-consensual sexual experiences occur. National and sub-national studies of young people should be conducted in a wide range of settings to highlight the pervasiveness of non-consensual sex among the young and dispel beliefs that non-consensual sex remains a rare event. Indeed, the accumulation of strong research evidence may have been a key factor shaping the stringent recent Sexual Offences Act in South Africa, and such evidence may well motivate policy change in other settings as well.

\section{References and related publications}

Ajuwon, A.J. and W.R. Brieger. 2007. "Evaluation of a school-based reproductive health education programme in rural South Western Nigeria." African Journal of Reproductive Health 11(2): 47-59.

Askew, lan, Jane Chege, and Carolune Njue. 2004. "A multi-sectoral approach to providing reproductive health information and services to young people in Western Kenya: Kenya Adolescent Reproductive Health Project." Nairobi: Population Council.

Bott, S., A.C. Guedes, A. Guezmes. 2005. "The health service response to sexual violence: Lessons from IPPF/WHR member associations in Latin America," In S. Jejeebhoy, I. Shah, and S. Thapa (eds.), Sex Without Consent: Young People in Developing Countries. London: Zed Books, pp. 251-268.

Brady, M. and A.B. Khan. 2002. Letting Girls Play: The Mathare Youth Sports Association's Football Program for Girls. New York: Population Council.

Erulkar, Annabel. 2004. "The experience of sexual coercion among young people in Kenya," International Family Planning Perspectives 30(4): 182-189.

Erulkar, A., T. Ab Mekbib, N. Simie, T. Gulema. 2005a. Adolescent Life in Low Income and Slum Areas of Addis Ababa, Ethiopia. Accra: Population Council.

Erulkar, A., T. Ab Mekbib, N. Simie, T. Gulema. 2005b. The Experience of Adolescence in Rural Amhara Region, Ethiopia.Accra: Population Council.

Erulkar, Annabel S. and James K. Matheka. 2007. "Adolescence in the Kibera slums of Nairobi." Nairobi, Kenya: Population Council.

Hallman, K. 2005. "Gendered socioeconomic conditions and HIV risk behaviours among young people in South Africa," African Journal of AIDS Research 4(1): 37-50.

Hallman, K. and E. Roca. 2011. "Siyakha Nentsha: Building economic, health and social capabilities among highly vulnerable adolescents in KwaZuluNatal, South Africa." Providing Health, Safe, and Productive Transitions to Adulthood Brief No.4. New York: Population Council. 
International Institute for Population Sciences (IIPS) and Population Council (PC). 2010. Youth in India: Situation and Needs 2006-2007. Mumbai: IIPS

Jejeebhoy, Shireen, Iqbal Shah, and Shyam Thapa (eds.). 2005. Sex Without Consent: Young People in Developing Countries. London: Zed Books.

Jejeebhoy, Shireen J., K.G. Santhya and Rajib Acharya. 2010. "Health and social consequences of marital violence: A synthesis of evidence from India." New Delhi: Population Council and UNFPA.

Jewkes, Rachel, M. Nduna, J. Levin, et al. 2008. "Impact of Stepping Stones on incidence of HIV and HSV-2 and sexual behaviour in rural South Africa: cluster randomised controlled trial." BMJ 337: a506.

Koenig, M.A., I. Zablotska, T. Lutalo, et al. 2005. "Coerced first intercourse and reproductive health among adolescent women in Rakai, Uganda," in S. Jejeebhoy, I. Shah, and S. Thapa (eds.), Sex Without Consent: Young People in Developing Countries. London: Zed Books, pp. 186-202.

Maharaj, P. and C. Munthree. 2007. "Coerced first sexual intercourse and selected reproductive health outcomes among young women in KwaZuluNatal, South Africa." Journal of Biosocial Science 39(2): 231-244.

Mgalla, Z., D. Schapink, and J. Ties Boerma.1998. "Protecting school girls against sexual exploitation: a guardian programme in Mwanza, Tanzania." Reproductive Health Matters 7(12): 19-30.

Mirsky, J. 2005. "Developing opportunities within the educational sector to prevent non-consensual sexual experiences: An emerging issue for human rights, public health and education development goals," in S. Jejeebhoy, I. Shah, and S. Thapa (eds.), Sex Without Consent: Young People in Developing Countries. London: Zed Books, pp. 236-250.

National Research Council (NRC) and Institute of Medicine (IM). 2005. Growing Up Global: The Changing Transitions to Adulthood in Developing Countries. Panel on Transitions to Adulthood in Developing Countries, ed. Cynthia B. Lloyd. Washington, DC: National Academies Press.

Natividad, JN. and M. Marquez. 2004. "Sexual risk behaviours," in C. Raymundo and G. Cruz (eds), Youth Sex and Risk Behaviours in the Philippines, Quezon City, Demographic Research and Development Foundation Inc, UP Population Institute.
Peacock, Dean and Andrew Levack. 2004. "The men as partner program in South Africa: Reaching men to end gender-based violence and promote sexual and reproductive health." International Journal of Men's Health 3(3): 173-188.

Patel, V. and G. Andrew. "Coercive sex and psycho-social outcomes in adolescents: exploring the role of parental relationships," In Jejeebhoy, Shireen, Iqbal Shah, and Shyam Thapa (eds.). 2005. Sex Without Consent: Young People in Developing Countries. London: Zed Books, pp. 203-212.

Population Council. 2010. "The adolescent experience in-depth: Using data to identify and reach the most vulnerable young people." New York. http://www.popcouncil.org/publications/serialsbriefs/AdolExplnDepth.asp.

Ross, D.A., J. Changalucha, A.I.N. Obasi, et al. 2007. "Biological and behavioural impact of an adolescent sexual health intervention in Tanzania: $A$ community-randomized trial." AIDS 21: 1943-1955.

Santhya, K.G. and S.J. Jejeebhoy. 2005. "Young women's experiences of forced sex within marriage: Evidence from India," In Jejeebhoy, Shireen, lqbal Shah, and Shyam Thapa (eds.). Sex Without Consent: Young People in Developing Countries. London: Zed Books, pp. 59-73.

UNIFEM. 2010. A Life Free of Violence: Unleashing the Power of Women's Empowerment and Gender Equality. New York.

World Health Organization (WHO). 2005. WHO Multi-Country Study on Women's Health and Domestic Violence against Women. Geneva.

Wu, J., L. Want, G. Zhao, and X. Zhang. 2006. "Sexual abuse and reproductive health among unmarried young women seeking abortion in China," International Journal of Gynecology \& Obstetrics 92(2): 186-191.

\section{Donors and contributing organizations}

UK Department for International Development (DFID), Family Health International (FHI), The Ford Foundation, The John D. and Catherine T. MacArthur Foundation, Population Council, The Rockefeller Foundation, United Nations Development Programme (UNDP), United Nations Population Fund (UNFPA), United States Agency for International Development (USAID), World Bank, David and Lucile Packard Foundation, UNFPA, World Health Organization (WHO)

\section{(f) Population Council}

The Population Council changes the way the world thinks about critical health and development issues. We seek to understand the causes and consequences of gender inequality and the disparities in opportunity that arise during adolescence. We provide the evidence for better on-theground programs and policies that ensure successful and productive transitions to adulthood in developing countries. www.popcouncil.org

(c) 2011 The Population Council, Inc. 